\title{
KAJIAN VARIASI JARAK TANAM DAN DOSIS PUPUK DOLOMIT TERHADAP PERTUMBUHAN KACANG TANAH (Arachys hipogeae L) DI LAHAN PASANG SURUT
}

\author{
Tengku Boumedine Hamid Zulkifli \\ Prodi Agroteknologi, Fakultas Pertanian, Universitas Tut Nyak Dhien, email: tengku_bobhz@yahoo.co.id \\ Irwan Agusnu Putra \\ Prodi Agroteknologi, Fakultas Pertanian, Universitas Tut Nyak Dhien, email: irwan agusnu@yahoo.co.id
}

\begin{abstract}
Abstrak
Penelitian ini bertujuan untuk mengetahui jarak tanam dan pemberian dolomite di Lahan Pasang Surut. Penelitian ini dilaksanakan lahan pasang surut yang ada di Desa Sei Ular , Kecamatan Secanggang, Kabupaten Langkat dengan ketinggian tempat $\pm 1 \mathrm{~m}$ dpl selama 4 bulan Juni - September 2014). Tujuan jangka panjang dari penelitian ini adalah dapat kiranya ditentukan diharapkan dapat menekan $\mathrm{Na}^{+}$dalam tanah, sehingga dapat $\mathrm{pH}$ Tanah menjadi sesuai bagi tanaman kacang tanah. Penelitian dilakukan dengan menggunakan rancangan acak kelompok (RAK) Faktorial terdiri dari dua faktor yaitu : Faktor pertama : Variasi Jarak Tanam (J) yakni : $\mathrm{J}_{0}=\mathrm{Jarak}_{\mathrm{K}}$ Tanam $20 \mathrm{~cm} \times 20$ $\mathrm{cm}, \mathrm{J}_{1}=$ Jarak Tanam $30 \mathrm{~cm}$ x $20 \mathrm{~cm} \quad \mathrm{~J}_{2}=$ Jarak Tanam $40 \mathrm{~cm}$ x $20 \mathrm{~cm}$. Faktor Kedua : Pupuk Dolomit (D), yakni $\mathrm{D}_{0}=0 /$ plot, $\mathrm{D}_{1}=3$ ton/ha, $\mathrm{D}_{2}=6$ ton/ha $\mathrm{D}_{3}=9$ ton/ha. Penelitian ini diharapkan dapat memberikan hasil produksi yang nyata. Hasil penelitian menunjukkan bahwa pemberian perlakuan jarak tanam dan pupuk dolomite pada tanaman kacang tanah memberikan hasil yang nyata pada beberapa pengamatan. Pemberian pupuk dolomite mampu memberikan tekanan atau mengurangi kadar Na di lahan pasang surut.
\end{abstract}

Kata Kunci: Kacang tanah, Dolomit, jarak tanam, intrusi air laut, lahan pasang surut

\section{PENDAHULUAN}

Kacang tanah (Arachis hypogaea L.)merupakan tanaman legum terpenting setelah kedelai yang memiliki peran strategis dalam pangan nasional sebagai sumber protein dan minyak nabati. Sebagai bahan pangan dan makanan yang bergizi tinggi (Suprapto, 1999).

Peranan kacang tanah pada dasawarsa terakhir ini semakin meningkat dalam kaitannya dengan penyediaan bahan baku industri, namun perkembangan produksinya kurang menggembirakan dengan pertambahan lusa panen sebesar $1,27 \%$ dengan hasil sebesar 1.043 ton/ha (Prasetyo, 2003).

Menurut Badan Pusat Statistik, (2013), bahwa produksi kacang tanah di Indonesia pada tahun 2013 ini sebesar 786.868 ton dengan luasan panen sebesar 541.340 ha.

Lahan Pasang surut dikategorikan merupakan lahan yang kurang subur dan menurut Anonimus, 2013. Jarak tanam pada lahan yang kurang subur yakni $40 \mathrm{~cm} \times 10 \mathrm{~cm}$ atau $20 \mathrm{~cm}$ x $20 \mathrm{~cm}$. Untuk menghasilkan kacang tanah sekitar 2,0 ton polong kering/ha dilahan pasang surut diperlukan jarak tanam 40 x $10 \mathrm{~cm}$ ( Saragih dan Raihan, 1996).

Lahan pasang surut umumnya memiliki kemasaman tanah tinggi ( $\mathrm{pH}$ rendah), miskin hara yang esensial bagi kacang tanah yakni $\mathrm{P}, \mathrm{K}$ dan $\mathrm{Ca}$, serta kelebihan unsur $\mathrm{Al}$ dan $\mathrm{Fe}$ yang bersifat racun bagi tanaman (Ismunadji dan Partoharjono, 1985 ; Murtado dan Ismunadji, 1988 dalam Kasno, A., 2006).

Unsur Ca (Kalsium) sangat diperlukan untuk kebutuhan tanaman kacang tanah untuk pembentukan polong. Pada penelitian Saragih dan Raihan, 1996, bahwa pemberian kapur sebanyak 1,5 hingga 2,0 ton/ha sangat efektif dalam pengendalian senyawa toksik di lahan pasang surut. Menurut penelitian Balitra, 1998 dalam Sudana, W., (2005), pemberian kapur sebanyak 1- 3 ton/ha akan meningkatkan hasil produksi padi di lahan sulfat masam pasang surut, demikian juga pada penelitian Suwarno, dkk., 2000, menjelaskan bahwa pemberian kapur sebanyak 1 ton/ha dapat meningkatkan hasil produksi kacang tanah dilahan pasang surut

\section{METODE}

Waktu dan Tempat Penelitian

Pelaksanaan penelitian dimulai pada Bulan Februari 2014 sampai Juli mulai dari persiapan media lahan hingga panen. Penelitian akan dilaksanakan di Desa Sei Ular, Kecamatan Secanggang Kabupaten Langkat

\section{Bahan dan Alat Pertanian \\ Bahan :}

Lahan yang digunakan dalam penelitian ini adalah lahan pasang surut yang ada didaerah Desa Sei Ular, Kecamatan Secanggang. Kabupaten Langkat. Kacang Tanah varietas kelinci, dolomite $\left(\mathrm{CaMg}\left(\mathrm{CO}_{3}\right)_{2}\right)$, Urea, SP-36, $\mathrm{KCl}$ dan bahan - bahan lain yang mendukung penelitian ini.

Alat:

Alat-alat yang digunakan : cangkul, gembor, label nama, alat tulis, plastik, ember, meteran dan lainlain. 


\section{Model Rancangan}

Penelitian dilakukan dengan menggunakan rancangan acak kelompok (RAK) Faktorial terdiri dari tiga faktor yaitu :

Faktor pertama : Variasi Jarak Tanam (J) yakni :

$\mathrm{J}_{0}=$ Jarak Tanam $20 \mathrm{~cm} \mathrm{x} 20 \mathrm{~cm}$

$\mathrm{J}_{1}=$ Jarak Tanam $30 \mathrm{~cm} \times 20 \mathrm{~cm}$

$\mathrm{J}_{2}=$ Jarak Tanam $40 \mathrm{~cm} \times 20 \mathrm{~cm}$

Faktor Kedua : Pupuk Dolomit (D), yakni :

$\mathrm{D}_{0}=0 /$ plot

$\mathrm{D}_{1}=3$ ton $/$ ha

$\mathrm{D}_{2}=6$ ton/ha

$\mathrm{D}_{3}=9$ ton $/$ ha

Peubah amatan yang diamati adalah :

Tinggi Tanaman $(\mathrm{cm})$, Luas daun, berat basah tanaman dan berat bersih tanaman

\section{HASIL DAN PEMBAHASAN}

\section{Tinggi Tanaman $(\mathbf{c m})$}

Data hasil pengamatan dan analisis sidik ragam tinggi tanaman kacang tanah umur 3 MST, 5 MST, 7 MST dan 9 MST terlihat bahwa tinggi tanaman menunjukkan pengaruh yang nyata pada perlakuan jarak tanam umur 3 MST, memberikan pengaruh yang nyata pada tanaman kacang tanah pada perlakuan jarak tanam dan pemberian dolomit umur 5 MST dan 7 MST sedangkan pada umur 9 MST tidak memberikan pengaruh yang nyata.. Pada interaksinya antar perlakuan memberikan pengaruh yang nyata terhadap pertumbuhan tinggi tanaman umur 5 MST (Lampiran 8) dan umur 7 MST ( ampiran 10).

Hasil uji tinggi tanaman terhadap interaksi perlakuan jarak tanam dan dolomit $\mathrm{p}$ pada tanaman kacang tanah disajikan pada Tabel 1.

Pada Tabel 1 terlihat bahwa interaksi perlakuan jarak tanam dan pemberian dolomit pada tinggi tanaman kacang tanah yang terlihat pada rataan perlakuan $\mathrm{J}_{1} \mathrm{D}_{2}$ dengan nilai tertinggi $27,80 \mathrm{~cm}$

Interaksi perlakuan jarak tanam dan pemberian dolomit pada tinggi tanaman kacang tanah umur 5 MST dapat dilihat pada gambar grafik dibawah ini. Pada gambar 1 diagram dapat dilihat hubungan jarak tanam dengan tinggi tanaman kacang tanah umur 7 MST

\section{Luas Daun $\left(\mathrm{cm}^{2}\right)$}

Hasil pengamatan luas daun $\left(\mathrm{cm}^{2}\right)$ kacang tanah umur 3 MST (lampiran 14) , 5 MST (lampiran 16), 7 MST (lampiran 18) dan 9 MST (lampiran 20) serta sidik ragamnya dapat dilihat pada Lampiran 15, lampiran 17, lampiran 19 dan lampiran 21 . Dari hasil analisis diperoleh bahwa luas daun $\left(\mathrm{cm}^{2}\right)$ tanaman kacang tanah memberikan perbedaan yang nyata pada jarak tanam umur 3 MST (lampiran 15), umur 5 MST (lampiran 17) pada pemberian dolomit dan umur 7 MST (lampiran 19) memberikan perbedaan yang nyata pada jarak tanam dan pemberian dolomit serta pada umur 9 MST tidak memberikan penagaruh yang nyata pada perlakuan. Pada interaksinya memberikan pengaruh yang nyata pada umur 7 MST (lampiran 19).
Hasil uji luas daun $\left(\mathrm{cm}^{2}\right)$ pada interaksi perlakuan jarak tanam dan pemberian pupuk dolomit pada tanaman kacang tanah umur 7 MST di lahan pasang surut disajikan pada Tabel 3 .

Berdasarkan Tabel 3, terlihat bahwa interaksi perlakuan pada jarak tanam dan pemberian pupuk dolomit pada kacang tanah umur 7 MST.pada luas daun tanaman kacang tanah yang terlihat pada rataan perlakuan $\mathrm{J}_{1} \mathrm{D}_{2}$ dengan nilai tertinggi $250,50 \mathrm{~cm}^{2}$.

Interaksi perlakuan jarak tanam dan pemberian dolomit pada tinggi tanaman kacang tanah umur 7 MST dapat dilihat pada gambar grafik dibawah ini.

\section{Pembahasan}

1. Penggunaan jarak tanam di lahan pasang surut dapat meningkatkan pertumbuhan dan produksi kacang tanah

Penggunaan jarak tanam dilahan pasang surut dengan ukuran $\mathrm{J} 0=20 \mathrm{~cm} \times 20 \mathrm{~cm}, \mathrm{~J} 1=30$ $\mathrm{cm} \times 20 \mathrm{~cm}$ dan $\mathrm{J} 2=40 \mathrm{~cm} \times 20 \mathrm{~cm}$ dalam penelitian ini memberikan pengaruh yang nyata pada tinggi tanaman umur 3 MST (lampiran 07), umur 5 MST (lampiran 09) dan umur 7 MST (lampiran 11). Pada parameter pengamatan luas daun juga memberikan pengaruh yang nyata pada umur 3 MST (lampiran 17) dan umur 7 MST (lampiran 19), Jarak tanam memberikan perbedaan tidak nyata pada tinggi tanaman umur 9 MST (lampiran 13), luas daun umur 5 MST (lampiran 17) dan umur 9 MST (lampiran 21). Dari penelitian ini dapat juga dilihat bahwa jarak tanam dengan ukuran $30 \mathrm{~cm}$ x $20 \mathrm{~cm}$ dan jarak tanam ukuran $40 \mathrm{~cm}$ x $20 \mathrm{~cm}$ merupakan ukuran yang terbaik dilahan pasang surut. Hal ini disebabkan karena jarak tanam yang luas menyebabkan tanaman tidak bersaing dalam penyerapan unsur hara dan cahaya. Menurut Sitompul dan Guritno, (1995) menyatakan jarak tanam merupakan salah satu cara untuk ciptakan faktorfaktor lingkungan dan hara dapat tersedia secara merata bagi setiap individu tanaman, demikian juga menurut penelitian Sudadi, (2003), menyatakan bahwa faktor lingkungan terutama kelembaban dan suhu di sekitar tanaman sangat mempengaruhi pertumbuhan dan hasil tanaman.Pada penelitian Budiastuti, (2000), menyatakan bahwa jarak tanam yang renggang maka penerimaan intensitas cahaya matahari lebih besar sehingga tanaman melakukan pertumbuhan kesamping dan mempercepat terbentuknya percabangan tanaman.

\section{Pemberian pupuk dolomit di lahan pasang surut dpat meningkatkan pertumbuhan dan produksi kacang tanah.}

Pemberian pupuk dolomit sebanyak 3 ton/ha, 6 ton/ha dan 9 ton/ha dalam penelitian ini memberikan pengaruh yang nyata pada tinggi tanaman umur 5 MST (lampiran 09) dan umur 7 MST (lampiran 11) dan memberikan hasil yang tidak nyata pada tinggi tanaman umur 3 MST (lampiran 07) dan umur 9 MST (lampiran 13). Pada pengamatan luas daun memberikan pengaruh yang nyata pada umur 5 MST (lampiran 17) dan umur 7 MST (lampiran 19) dan tidak memberikan hasil yang tidak nyata pada luas daun umur 3 MST (lampiran 15) dan umur 9 MST (lampiran 21), Pemberian pupuk 
dolomit memberikan hasil yang nyata disebabkan karena pemberian dolomit dapat meningkatkan unsur hara lain, hal ini terdapat dalam penelitian Sumaryo dan Suryono, 2000, menyatakan bahwa hara $\mathrm{Ca}$ dan $\mathrm{Mg}$ pada dolomit bukan saja dapat meningkatkan ketersediaan unsurhara lain juga dapat memperbaiki sifat fisik tanah, dengan demikian pertumbuhan tanaman menjadi lebih baik. Selanjutnya Sumaryo dan Suryono, 2000, menyatakan bahwa dengan meningkatnya ketersediaan $\mathrm{Ca}$ dan $\mathrm{Mg}$ dalam tanah akan mempercepat tugor sel dan pembentukan khlorofil dan proses foto sintesis juga meningkat. Sebagian fotosintesis digunakan bintil akar umtuk pertumbuhannya dan pemberian dolomit dapat meningkatkan pembentukah jumlah bintil akar sehingga mempercepat proses pertumbuhan tanaman kacang tanah.

Pada penelitian ini luas daun memberikan pengaruh yang nyata pada umur 5 MST (lampiran 17) dan umur 7 MST (lampiran 19), Ini disebabkan karena pemberian pupuk dolomite yang terdiri dari unsure $\mathrm{Ca}$ dan $\mathrm{Mg}$ dapat meningkatkan luas daun tanaman kacang tanah karena fungsi $\mathrm{Ca}$ dan $\mathrm{Mg}$ adalah untuk meningkatkan jumlah khlorofil daun, dengan bertambahnya jumlah pemberian dolomite pada tanah maka penyerapan dolomite yang terdiri dari unsure hara $\mathrm{Ca}$ dan $\mathrm{Mg}$ semakin meningkat pada umur tanaman 5 MST, umur 7 MST dan secara perlahan akan berkurang dan penyerapan $\mathrm{Ca}$ akan menurun karena tanaman sudah berbunga dan tanaman sudah menjelang ke fase pembentukan polong sehingga luas daun menjadi berkurang dengan bertambahnya usia tanaman. Menurut Tisdale, dkk, (1993), tersedianya unsur Ca dan Mg yang cukup pada lahan pasang surut selama satu bulan (4 minggu pertama)akan meningkatkan luas daun, hal ini berkaitan dengan tersedianya $\mathrm{N}$ dan $\mathrm{K}$ yang seimbang dalam tanah sehingga Nitrogen $(\mathrm{N})$ yang cukup tersedia akan membuat pertumbuhan tanaman menjadi vigor.

\section{Interaksi Variasi Jarak Tanam dan Dosis Pupuk Dolomit dapat meningkatkan pertumbuhan dan produksi kacang tanah (Arachis hipogeae L) di lahan pasang surut.}

Interaksi antara variasi jarak tanam dengan pemberian pupuk dolomite memberikan pengaruh yang nyata pada tinggi tanaman umur 5 MST dan umur 7 MST serta tidak nyata pada umur 3 MST dan umur 9 MST. Pada amatan luas daun memberikan pengaruh yang nyata umur 7 MST dan tidak nyata umur 3 MST, 5 MST dan 9 MST. Pada analis tanah sebelum tanam bahwa ketersediaan $\mathrm{N}, \mathrm{K}, \mathrm{Ca}, \mathrm{Mg}$ (lampiran 3) rendah (lampiran 4), tetapi setelah diberi pupuk dolomite ketersediaan $\mathrm{Ca}, \mathrm{Mg}$ tinggi dan ketersediaan $\mathrm{N}$ dan $\mathrm{K}$ meningkat pula, Salinitas pada lahan pasang surut dapat ditekan sehinngga pada umur 5 MST dan 7 MST tinggi tanaman, luas daun dan berat kering tanaman menjadi nyata,karena proses penyerapan calsium pada kacang tanah paling aktif pada minggu 5 MST dan 7 MST. Demikian juga pada variasi jarak tanam semakin luas jarak tanam proses penyerapan hara menjadi baik

\section{PENUTUP}

\section{Kesimpulan}

1. Variasi jarak tanam dilahan pasang surut dapat memberikan perbedaan yang nyata pada tinggi tanaman, luas daun.

2. Pemberian dolomite dilahan pasang surut dapat memberikan perbedaan yang nyata pada tinggi tanaman, luas daun.

3. Interaksi variasi jarak tanam dan pemberian dolomite dapat emberikan perbedaan yang nyata pada tinggi tanaman, luas daun,

4. Jarak tanam ukuran $30 \mathrm{~cm} \times 20 \mathrm{~cm}$ dan ukuran $40 \mathrm{~cm}$ x $20 \mathrm{~cm}$ dapat memberikan hasil yang baik dilahan pasang surut

5. Pemberian dolomite 6 ton dan 9 ton pada lahan pasang surut dapat menaikkan $\mathrm{pH}$ dan unsure hara dalam tanah dan meningkatkan ketersediaan hara lainnya serta menekan kandungan salinitas tanah dilahan pasang surut.

Saran

1. Perlu dilakukan penelitian yang lebih lanjut ketahap hibah bersaing untuk meneliti ketersediaan hara yang lain dan penekanan dolomite dalam menekan Salinitas di lahan pasang surut.

2. Penanaman tanaman pangan dilahan pasang surut perlu dilakukan untuk swasembada tanaman pangan nasional.

\section{DAFTAR PUSTAKA}

AAK., 2007. Kacang Tanah. Penerbit Kanisius

Abdurachman dan E.E. Ananto. 2000. Konsep Pengembangan Pertanian Berkelanjutan di Lahan Rawa untuk Mendukung Ketahanan Pangan dan Pengembangan Agribisnis dalam Suriadikarta, D.A dan Mas Teddy Sutriadi. Jenis-Jenis Lahan berpotensi Untuk Pengembangan Pertanian di lahan Rawa. Jurnal Litbang Pertanian 2007.

Alihamsyah, T. 2004. Potensi dan Pendayagunaan Lahan Rawa untuk Peningkatan Produksi Padi. Ekonomi Padi dan Beras Indonesia. Badan Litbang Pertanian, Jakarta. Hal. 141-151

Adisarwanto, T. 2007. Meningkatkan Produksi Kacang Tanah di Lahan Sawah dan Lahan Kering. Penerbit Penebar Swadaya.

Eri Sudewo, 1991. Studi Peranan Pemberian Gipsun dan Pencucian Serta Penambahan Kalium dan Magnesium Terhadap Sifat Kinmia Tanah dan Produksi Padi Sawah Pada Tanah Terintrusi Air Asin Indramayu, Jawa Barat. Jurusan Tanah. Fakultas Pertanian IPB. Hal. 1-22.

Follet, R. H., L. S Murphy, and R. L Donahue, 1981. Fertilizers and Soil Amandments. Prentice-Hall, Inc. Englewood Cliffs. New Jersey. 
Agrinula. Volume 01 Nomor 01 Tahun 2016, 1 - 4

Gomez, K. A. dan A. A. Gomez. 2007. Prosedur Statistika untuk Penelitian Pertanian. Terjemahan : Sjamsudin, E dan J. S. Baharsyah. UI-Press.

Hartatik dan Widiowati, 2009. Pupuk Kandang. Pupuk Organik dan Pupuk Hayati. Hal. 51-82 